International Journal of Business Management and Economic Review

Vol. 4, No. 04; 2021

ISSN: 2581-4664

\title{
THE EFFECT OF APPARATUS ABILITY ON WORK MOTIVATION AND ITS IMPACT ON PUBLIC SERVICE PERFORMANCE OF REGIONAL SECRETARIAT OF PIDIE JAYA REGENCY
}

\author{
Said Syarif Salahuddin, Mukhlis and Said Musnadi \\ Management Department, UniversitasSyiah Kuala, Indonesia \\ http://doi.org/10.35409/IJBMER.2021.3286
}

\begin{abstract}
This study aims to examine the effect of the ability of the state civil apparatus on work motivation and its impact on the performance of public services at the Regional Secretariat of Pidie Jaya Regency (SetdakabPijay), Indonesia. In this study there were 2 types of population, the first population was all employees of the SetdakabPijay, totaling 221 employees and the second population was the people of Pidie Jaya regency. The method used in this study for the first population was the census method, while the number of people who were not known, it was determined that the number of the sample taken was as much as the number of employees who work at the SetdakabPijay. The research model was analyzed using Structural Equation Modelling (SEM). The results of the descriptive hypothesis test show the ability of the apparatus, work motivation, and performance of public services at the SetdakabPijayare already in good condition (H1). The results of direct hypothesis testing indicate that the ability of the apparatus has a positive and significant effect on work motivation (H2), the ability of the apparatus has a positive and significant effect on public service performance (H3), and work motivation has a positive and significant effect on public service performance (H4). The results of indirect hypothesis testing (H5) prove that work motivation partially mediates the effect of the ability of the apparatus on the performance of public services at the SetdakabPijay. Thus, the results of the model test prove that the public service performance improvement model at the SekdakabPijay is acceptable, namely to improve public service performance the predictor that must be improved is the apparatus ability, so that it will have a direct impact on public service performance or will affect the increase in work motivation at the beginning and ends in improving public service performance.
\end{abstract}

Keyword: Apparatus Ability, Work Motivation, Public Service Performance.

\section{INTRODUCTION}

As a region that has received relatively new autonomy rights, the Pidie Jaya Regency Government (in the district of Pidie Jaya, Indonesia) faces its own dynamics and challenges in its efforts to advance and improve people's welfare, accelerate regional development and in particular to support national development. These dynamics and challenges make this district have to work hard and strive in preparing various administrative, social and other development infrastructure so that the ideals of this district which are reflected in the vision and mission of the Pidie Jaya Regency Government can be quickly realized. The dynamics and challenges in the 


\section{International Journal of Business Management and Economic Review}

Vol. 4, No. 04; 2021

ISSN: 2581-4664

form of human resources, finance, social development, technological developments and increasingly diverse community demands have made the policies and services carried out by the district government no longer be treated as business as usual but must be handled by adopting a breakthrough policy that can be used. accelerate the development process and the service itself.

The Regional Secretariat of Pidie Jaya Regency (SetdakabPijay) is one of the Government Institutions (SKPDs) within the Pidie Jaya Regency Government as stated in the Qanun of the Pidie Jaya Regent No 4/2016 which has a very important role in realizing the achievement of the vision and mission of the Pidie Jaya Regency Government. As a main organizational instrument in the Pidie Jaya Regency Government, the SetdakabPijay is expected to be more responsive in responding to the various demands for changes that occur, by being more creative and innovative in interpreting the rules according to the needs and expectations of the community(Muttaqin, Djumadi, \& Noor, 2013).

In this connection and in the framework of efforts to achieve organizational goals, the performance of the State Civil Apparatus (ASN) in the SetdakabPijay is required to be able to display their performance optimally to provide more satisfying services to the community. ASN as a public servant is required to provide professional and maximum service to the community. Public service is a form of service, either in the form of public goods or public services which are the responsibility of the Pidie JayaRegency Government, the goal is to serve the needs of the community following statutory provisions(Humas-Pijay, 2015).

Many theories and empirical studies have been conducted to identify the factors that can affect the performance of these public services. One of them is the ability of the apparatus and work motivation possessed by ASN and support from their superiors. We certainly feel and realize that the performance of public services so far is like a jungle where most people often experience uncertainty when dealing bureaucratically with government agencies, especially at regional level agencies, which causes people to be reluctant to deal directly with these public services.

Not optimal performance of public services provided by ASN is also a separate phenomenon that occurs in the SetdakabPijay environment. This is reflected in the absence of minimum service standards (SPM) and not maximally socialized. ASN as a public servant very often displays a lack of seriousness in providing services to the community, as well as the lack of quality human resources in providing public services, resulting in not maximizing the quality of public services displayed. This is reflected in the performance report (LAKIP) of the SetdakabPijay for the last 4 years as shown in table 1 below.

Table 1.LAKIP of SetdakabPijayfrom 2016 to 2019

\begin{tabular}{|c|c|c|c|c|c|c|}
\hline \multirow[b]{2}{*}{ No } & \multirow[b]{2}{*}{ Indicator } & \multicolumn{5}{|c|}{ Realization } \\
\hline & & 2016 & 2017 & 2018 & $\begin{array}{l}\text { Target } \\
2019\end{array}$ & $\begin{array}{l}\text { Realization } \\
2019\end{array}$ \\
\hline 1 & $\begin{array}{l}\text { Percentage of availability of } \\
\text { regional development planning } \\
\text { report documents }\end{array}$ & 8 & 10 & 10 & 10 & 10 \\
\hline 2 & $\begin{array}{l}\text { Value of Performance } \\
\text { Accountability of Pidie Jaya District } \\
\text { Government Agencies }\end{array}$ & $\mathrm{C}$ & $\mathrm{C}$ & $\mathrm{CC}$ & B & $\mathrm{CC}$ \\
\hline
\end{tabular}


International Journal of Business Management and Economic Review

Vol. 4, No. 04; 2021

ISSN: 2581-4664

\begin{tabular}{|l|l|l|l|l|l|l|}
\hline \hline \multirow{2}{*}{ No } & \multirow{2}{*}{ Indicator } & \multicolumn{3}{l}{ Realization } \\
\cline { 3 - 7 } & $\mathbf{2 0 1 6}$ & $\mathbf{2 0 1 7}$ & $\mathbf{2 0 1 8}$ & $\begin{array}{l}\text { Target } \\
\mathbf{2 0 1 9}\end{array}$ & $\begin{array}{l}\text { Realization } \\
\mathbf{2 0 1 9}\end{array}$ \\
\hline 3 & $\begin{array}{l}\text { LPPD Compilation Rank } \\
\text { Achievements }\end{array}$ & 10 & 17 & 14 & 8 & $\begin{array}{l}\text { not } \\
\text { known }\end{array}$ \\
\hline 4 & Inflation Rate & $2.79 \%$ & $2.80 \%$ & $3.17 \%$ & $4.25 \%$ & $3.17 \%$ \\
\hline 5 & $\begin{array}{l}\text { GRDP Per Capita at Constant Price } \\
\text { (Million) }\end{array}$ & 14.92 & 15.45 & 15.83 & 201.4 & 15.83 \\
\hline 6 & Poverty Line Population Percentage & $20.00 \%$ & $20.02 \%$ & $19.52 \%$ & $19.95 \%$ & $18.58 \%$ \\
\hline 7 & Open unemployment rate & $8.16 \%$ & $9.18 \%$ & $9.39 \%$ & $9.14 \%$ & $4.89 \%$ \\
\hline 8 & $\begin{array}{l}\text { Contribution of the agricultural } \\
\text { sector to GRDP }\end{array}$ & 40.57 & 40.57 & 46.60 & 47,15 & 46.60 \\
\hline 9 & $\begin{array}{l}\text { Contribution of the fisheries sector } \\
\text { to GRDP }\end{array}$ & 6.14 & 6.14 & 3.01 & 6.20 & 3.01 \\
\hline 10 & $\begin{array}{l}\text { Contribution of the trade sector to } \\
\text { GRDP }\end{array}$ & 2.67 & 8.63 & 5.30 & 9.52 & 5.30 \\
\hline 11 & $\begin{array}{l}\text { Contribution of the industrial sector } \\
\text { to GRDP }\end{array}$ & 3.55 & 5.32 & 5.03 & 3.90 & 5.03 \\
\hline 12 & PAD achievements & 91.99 & 89.31 & 82.00 & 82.58 & 86.73 \\
\hline 13 & Incoming investment value & $\begin{array}{l}18 \\
\text { Billion }\end{array}$ & 18 & 60 & 130 & 78.63 \\
Billion & Billionr & Billion & Billion \\
\hline
\end{tabular}

Source: SetdakabPijay(2020)

The aforementioned phenomena indicate that the quality of bureaucratic services is not optimal in providing services that have been enjoyed by the community. The question is, is it true that the performance of public services in Pidie Jaya Regency has not been optimal? And is the service performance that has not been maximal due to the lack of ability and low motivation of the apparatus? Based on the aforementioned phenomena, the author tries to comprehensively examine the Influence of the Ability of State Civil Apparatus on Work Motivation and Its Impact on Public Service Performance at the SetdakabPijay.

This research is based on some previous research both domestically and abroad as conducted by(Elwan, 2019), (Salijana, Toha, \& Helpiastuti, 2019), (Kasmi, 2017), (Rahma, Mattalatta, \& Abdullah, 2017), (Muttaqin et al., 2013), (Idris, 2012), (Anyim, Chidi, \& Badej, 2012), (Wright \& Pandey, 2008). Of all the research that has been done and quoted in this study, no research has been found that examines the role of work motivation in moderating the ability of state civil servants to public services at the SetdakabPijay. In this study, before testing the hypothesis either directly or indirectly, descriptive hypothesis testing will first be carried out where it will be seen how the conditions of each research variable are.

$\mathrm{Ha}_{1}$ : The capability of the State Civil Apparatus, Work Motivation, and Public Service Performance of the SetdakabPijayare already good.

In addition, the hypothesis of the effect of causality between the variables that can predict the improvement of public service performance at the Pijay Regional Secretariat, namely Apparatus Ability and work motivation, the basic theory of causality is explained in the following literature review section. 
International Journal of Business Management and Economic Review

Vol. 4, No. 04; 2021

ISSN: 2581-4664

\section{LITERATURE REVIEW}

\section{Apparatus Ability}

The government apparatus is an individual or group of people who serve the interests of the state and serve as civil servants(Tayibnapis, 1989), Meanwhile(Nirwandar, Tadju, \& Moerdiono, 1992)said that the government apparatus is the executive line of governmental activities who obtain their authority based on the delegation from the President of the Republic of Indonesia. In other words, the state apparatus is the implementer of the activities and processes of state government administration, both those working in the executive, legislative and judiciary bodies as well as those who are the TNI, the National Police, and Civil Servants which are determined by government regulations.

The state government apparatus is required to have very adequate knowledge skills, reliable skills, and good behavior attitudes, following the current provision of services and development(Handayaningrat, 1986). (Gibson, 1991) and (Soetopo, 1999)in his book mentioned the ability as a trait that is born or learned both mentally and physically. Meanwhile, skills are skills related to tasks. In carrying out their obligations as servants of the State, ASN is required to have the ability and skills that are very reliable in giving and carrying out their duties as an extension of the government to the community.

\section{Work Motivation}

(Robbins \& Judge, 2012)defined motivation as a process that explains the persistence, intensity, and direction of a person to achieve his goals both individually and in an organization. Intensity is related to the level of one's effort. In a governmental environment, work motivation is very important for civil servants to have because motivation is something that can encourage, channel, and support the behavior of civil servants so that they want to work more actively and enthusiastically in trying to achieve optimal results(Hasibuan, 2014).Meanwhile(Omolo, 2015)mentioned motivation as the key to the success of an organization in maintaining job continuity as well as a strong aid for survival. While(Maduka \& Okafor, 2014)stated motivation is the process of generating behavior, maintaining progress in behavior, and channeling specific behavioral actions.

The factor that influences work motivation is the ability of the apparatus. The level of professionalism or expertise in the service sector that is owned by the apparatus can be the cause of increased enthusiasm for work. The ability of the apparatus can be interpreted as the main requirement for government employees to complete their duties. How much ability the apparatus has can be seen through the knowledge and skills obtained from training and education that has been taken and the apparatus experience in working(Thoha, 2012).In his research(Idris, 2012)obtained the results that the ability of the apparatus can increase the work motivation of employees, especially in the field of service to the public.

$\mathrm{Ha}_{2}$ : The ability of the State Civil Apparatus affects the Work Motivation of the SetdakabPijay

\section{Public Service Performance}

Nowadays, the implementation of public services is often faced with conditions that are not following the needs, expectations and changes in various fields of community, national and state life. This is caused by the unpreparedness of ASN in responding to changes in values that have a 


\section{International Journal of Business Management and Economic Review}

Vol. 4, No. 04; 2021

ISSN: 2581-4664

wide dimension and the impact of various complex development problems. Meanwhile, the new order of Indonesian society is faced with global hopes and challenges triggered by advances in science, information, communication, transportation, investment and trade.

Public services (public) arise because of an obligation as a process of organizing organizational activities. The definition of public services based on Law No. 25/2009 concerning public services is stated as a series of activities in an effort to meet service needs in accordance with statutory regulations for every citizen and resident for goods, services, and/or administrative services provided by public service providers. In line with the above formula(Ratminto \& Winarsih, 2008)defined public services as all forms of services, both in the form of public goods and public services which in principle are the responsibility and are carried out by Government Agencies at the central, regional and in the BUMN or BUMD environment, in order to meet the needs of the community and in the context of implementing provisions legislation.

According(Halik, 2016), the main factors affecting service performance are expected service and perceived service. Another factor that affects public services is the ability of the apparatus. The ability of the apparatus greatly impacts the quality of public services. Professionalism is a reflection of the skills and expertise of the apparatus that can run effectively if it is supported by the suitability of the level of knowledge on the basis of an educational background with the workload that is their responsibility and also as a reflection of the selfpotential of the apparatus, both in terms of abilities and aspects of behavior which include loyalty. , innovation, productivity and creativity(Mathis \& Jackson, 2006).

One of the biggest challenges faced by government officials is the effort to display professionalism, a high work ethic, competitive advantage and the ability to uphold bureaucratic ethics in carrying out its duties and functions in accordance with the aspirations of a society that is free from the nuances of Corruption, Collusion and Nepotism (KKN). In order for the bureaucracy to provide good service, among the ten principles of good governance there are 3 (three) fundamental administrative-managerial values, namely: effectiveness, efficiency, and professionalism(Eko, 2015).

In (Rahmad, 2014)research stated that the ability of the apparatus greatly affects the quality of public services. The ability of the apparatus includes good cooperation and effective communication. Another research conducted by(Tian, Cordery, \& Gamble, 2016), (Rambi, Lengkong, \& Jorie, 2015), and(Hasanah, 2019) found that the ability of employees has a significant effect on performance.

$\mathrm{Ha}_{3}$ : The ability of the State Civil Apparatus affects the Public Service Performance of the SetdakabPijay

Apart from the factors mentioned above, work motivation factors can also affect public services. This is the same evident with research conducted by(Idris, 2012)where there was an associative relationship of work motivation with large public services. The same thing was proved by(Muttaqin et al., 2013)which revealed work motivation had a strong effect on public services. This increase in employee motivation is very meaningful for every organization, be it government organizations or organizations within the company. An employee who has a high motivation to work will provide the best for an organization.

Ha4 : Work Motivation affects the Public Service Performance of the SetdakabPijay 


\section{International Journal of Business Management and Economic Review}

Vol. 4, No. 04; 2021

ISSN: 2581-4664

Creating a quality service is not as easy as turning your hand. There are many factors that need to be considered carefully because efforts to improve service quality have a significant impact on the overall organizational culture. If the perception of service is following what the customer expects, then the quality of the service concerned will be assessed as good and positive. If the perception of service exceeds what the customer expects, service quality is ideal service quality. Conversely, if the service perception is worse than what the customer expects, then the service quality is bad. One of the factors influencing the quality of service is the factor of the ability of the apparatus and the factor of work motivation.

The high level of quality of public services will certainly increase the sense of community satisfaction felt by the community towards the services of government agencies. It needs to be realized, there are techniques to be able to improve service quality. One of them is by providing encouragement (motivation) to employees so that they can carry out their duties following the description and direction. Work motivation is a force that encourages someone to take any action or not. The higher / better the ability of an apparatus, the better the quality of service produced by that apparatus(Rahma et al., 2017). Work motivation also mediates the effect of the ability of the apparatus on public services. This is because the better the ability of the apparatus, the more the employee's work motivation will increase. With high work motivation, it directly improves the quality of public services.

Ha5: The ability of the State Civil Apparatus affects Public Service Performance through the Work Motivation of the SetdakabPijay Employees.

\section{Research Model}

This research model will explain the relationship between each variable on the improvement of work discipline which can be described as follows:

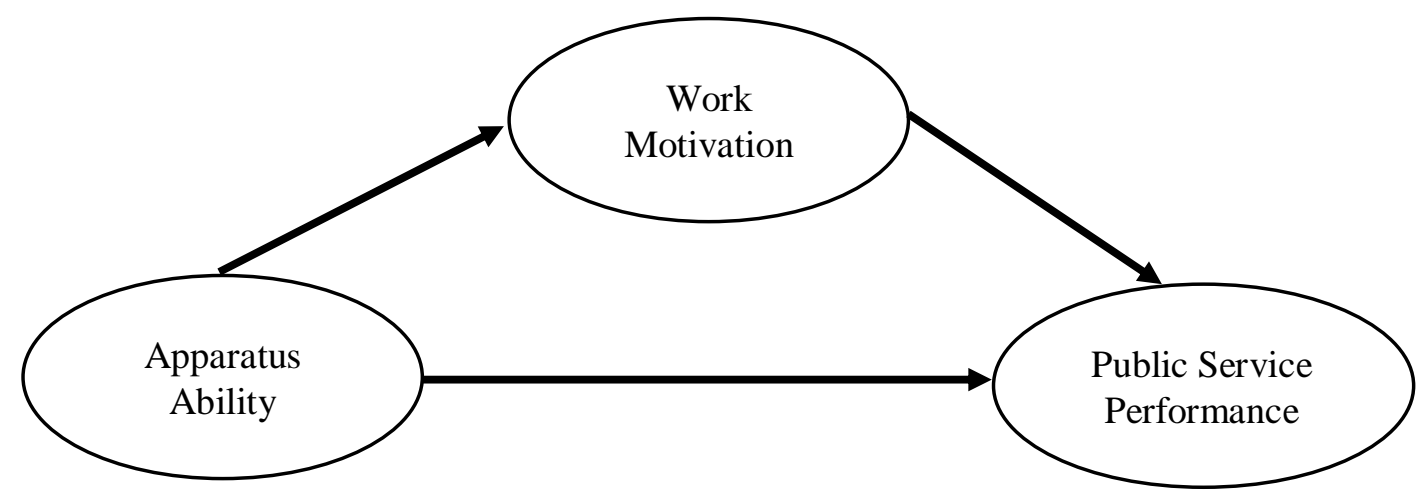

Figure 1. Research Model

\section{RESEARCH METHOD}

This research was conducted at the SetdakabPijay, while the object of research was the influence of the ability of the state civil apparatus of the SetdakabPijay. In this study, there were 2 types of population, the first population was all employees of SetdakabPijay, totaling 221 employees, consisting of 63 permanent employees and 158 non-permanent employees 


\section{International Journal of Business Management and Economic Review}

Vol. 4, No. 04; 2021

ISSN: 2581-4664

(contract/honorary). And the second population was the people of Pidie Jaya Regency. The method used in this study for the first population was the census method, this was because the population is relatively small. For work motivation variable that was sampled in this study was all employees as described above. As for the variables of the ability of the apparatus and the performance of public services, the sampletakenwas the people of Pidie Jaya Regency. Due to the number of people who were not known, it was determined that the number of sample taken was as many as the number of employees who work at the SetdakabPijay. Determination of community criteria as sample in this study was people who receive direct benefits from public services from the SetdakabPijay.

Furthermore, the data were collected using a questionnaire method, where the list of questions asked provides answers using a Likert scale. Measurement of variables in this study used the following indicators.

1. Public service performance is measured by indicators as disclosed by(Tjiptono, 1996)namely (1) timeliness of service, (2) accuracy of service, (3) politeness and friendliness, (4) ease of getting service, (5) convenience in obtaining services, (6) service support attributes.

2. Work motivation is measured using indicators as safety is expressed by(Hasibuan, 2014)namely (1) need for achievement, (2) need for affiliation, (3) need for competence, (4) trust, and (5) welfare.

3. The ability of the apparatus is measured using indicators as disclosed by(Nirwandar et al., 1992)namely (1) the level of education of the apparatus, (2) the ability to complete work according to schedule, (3) the ability to collaborate, (4) the ability to adapt to changes experienced by the organization, (5) the ability to arrange activity plans, (6) speed in implementingtasks, (7) the level of creativity in finding the best work procedure, (8) the level of ability to provide accountability to superiors, and (9) the level of participation in training related to their respective fields of work.

In this study, to test the descriptive hypothesis used a one-sample test with SPSS equipment. For direct hypothesis testing using SEM statistical equipment with the help of the AMOS program. The reason the writer used the statistical tool was that the variables used were latent variables. With SEM, latent variables can easily be measured with one measure. Furthermore, to test the indirect hypothesis (mediation) using a Sobel calculator. In this study, the mediating variable is work motivation.

\section{RESULT}

\section{Descriptive Hypothesis (Hypothesis 1)}

From the results of respondents' perceptions of each variable in this study as shown in Table 3 below

Table 2. Respondents' Perceptions of Variables

\begin{tabular}{|c|c|c|c|c|}
\hline No & Variable & Average & Cut off & Information \\
\hline 1 & Apparatus Ability (X) & 3.76 & \multirow{3}{*}{3.41} & Good \\
\hline 2 & Work Motivation(Y) & 3.95 & & Good \\
\hline 3 & Public Service Performance $(\mathrm{Z})$ & 3.78 & & Good \\
\hline
\end{tabular}




\section{International Journal of Business Management and Economic Review}

Vol. 4, No. 04; 2021

ISSN: 2581-4664

Source: Processed data (2021)

Based on the data in table 2, it shows that the respondents' perceptions of all variables in this study are already in good condition where all of these variables have obtained a mean value greater than 3.41. The next step is to do statistical testing using one sample T-test using a significant value $(\alpha=5 \%)$ and a cut-off value of 3.41. The criterion of this test is that if the significant value of the test is greater than 0.05 , the results of the descriptive hypothesis testing are that $\mathrm{H} 0$ is accepted and $\mathrm{Ha}$ is rejected. Likewise, if the test results show a significant value less than 0.05 , then $\mathrm{HO}$ is accepted and $\mathrm{Ha}$ is rejected. The following table shows the results of the one-sample test.

Table 3. Testing One-Sample T-Test

\begin{tabular}{|c|c|c|c|c|c|c|}
\hline & \multicolumn{6}{|c|}{ Test Value $=3.41$} \\
\hline & \multirow[t]{2}{*}{$\mathrm{t}$} & \multirow[t]{2}{*}{$\mathrm{df}$} & \multirow[t]{2}{*}{$\begin{array}{l}\text { Sig. } \\
\text { tailed) }\end{array}$} & \multirow[t]{2}{*}{$\begin{array}{l}\text { Mean } \\
\text { Difference }\end{array}$} & \multicolumn{2}{|c|}{$\begin{array}{ll}95 \% & \text { Confidence } \\
\text { Interval of the } \\
\text { Difference }\end{array}$} \\
\hline & & & & & Lower & Upper \\
\hline Apparatus Ability & 6.088 & 220 & .000 & .35149 & .2377 & .4653 \\
\hline Work Motivation & 8.694 & 220 & .000 & .53932 & .4171 & .6616 \\
\hline $\begin{array}{ll}\text { Public } & \text { Service } \\
\text { Performance } & \end{array}$ & 6.748 & 220 & .000 & .37181 & .2632 & .4804 \\
\hline
\end{tabular}

Sumber: Data processed (2021)

The test results of the one-sample t-test with a test value $=3.41$ as shown in table 3 above note that all variables show a sig value. (2-tailed) of $0.000<0.05$. With this, it can be concluded that the results of the descriptive hypothesis testing $(\mathrm{H} 1)$ are accepted where $\mathrm{Ha}$ is accepted and Ho is rejected. These results can be interpreted that the ability of the apparatus, work motivation, and performance of public services at the SetdakabPijay are already in good condition.

\section{Direct Effect Hypothesis Testing (Hypothesis 2, 3, and 4)}

Analysis of the results of data processing at the full model SEM stage was carried out by performing a suitability test and statistical test. The results of data processing for the full model SEM analysis are shown in the following Figure.

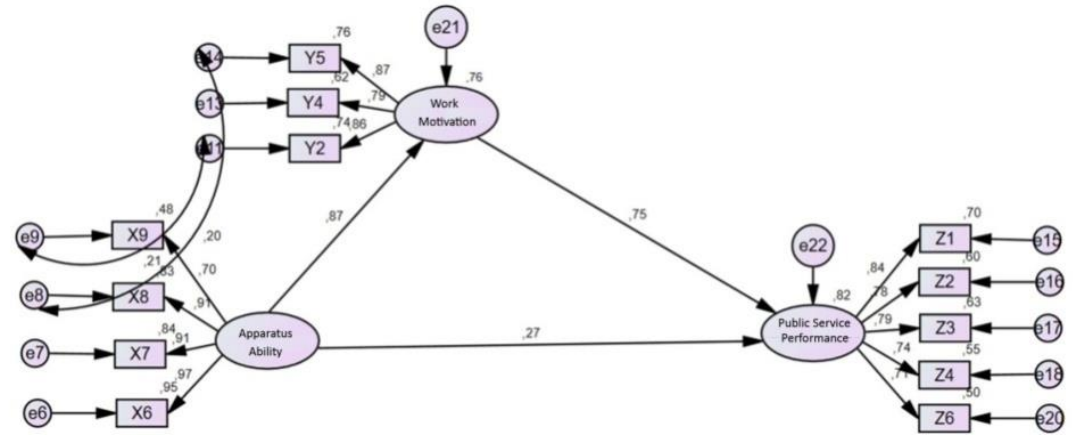


International Journal of Business Management and Economic Review

Vol. 4, No. 04; 2021

ISSN: 2581-4664

Figure 2.Structural Model Test Result

Based on SEM testing as shown in Figure 2 above, the following results were obtained.

Table 4. Results of Direct Effect Test

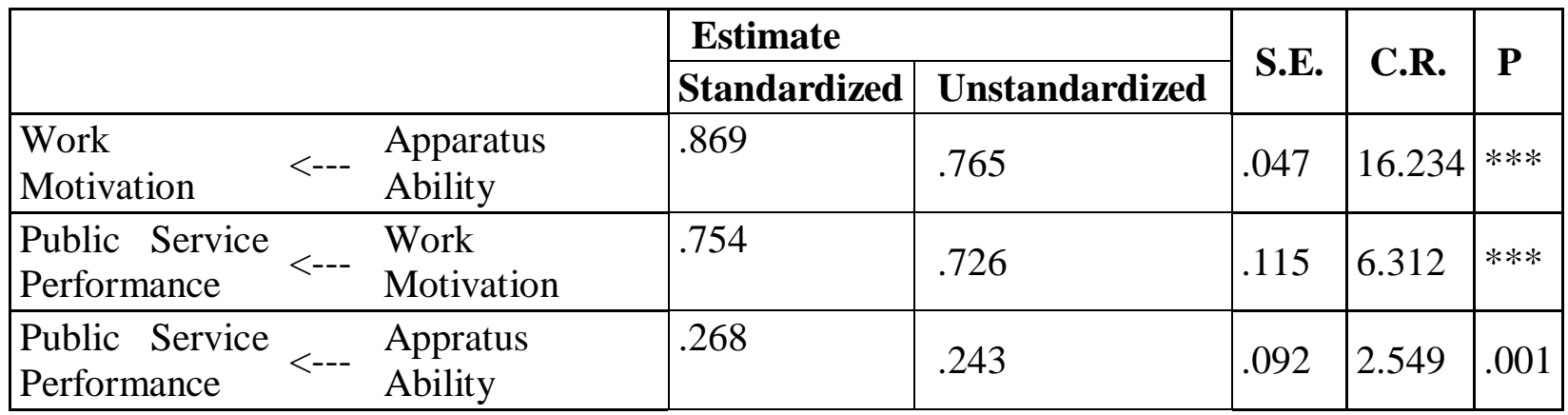

Sumber :Data primer, 2021(diolah)

Based on the results of the analysis of direct hypothesis testing in table 4 above, the statistical equations can be formulated as follows:

Work Motivation $\quad=0.869$ Appratus Ability

Public Service Performance $=0.268$ Appratus Ability +0.754 Work Motivation follows:

By looking at the test results above, the results of direct hypothesis testing can be explained as

Testing the Effect of Apparatus Ability on Employee Work Motivation at the SetdakabPijay (Hypothesis 2)

The results of hypothesis testing directly influence the ability of the apparatus on work motivation at the SetdakabPijay, obtained a Critical ratio (C.R) value of 16.234 where this value is greater than the cut-off value of 1.96 . The value of significance or probability is 0.000 where this value is also less than 0.05 . These results indicate that the ability of the apparatus has a positive and significant effect on work motivation or it can be called direct hypothesis testing (H2) which results in Ha2 being accepted and $\mathrm{H} 02$ being rejected. The magnitude of the influence of the ability of the apparatus on work motivation is 0.869 or $86.9 \%$. The results of this study are in line with the results of research conducted by(Idris, 2012)and(Thoha, 2012)wherein their research also obtained the results that the ability of the apparatus has a positive and significant effect on employee motivation.

The results of this study prove that the better the abilities or skills possessed by each state civil servant in the SetdakabPijay environment, the better their work motivation will be. The level of professionalism or expertise in the service sector that is owned by the apparatus can be the cause of increased enthusiasm for work. The ability of the apparatus can be interpreted as the main requirement for government employees to complete their duties. How much ability the apparatus has can be seen through the knowledge and skills obtained from training and education that has been taken and the apparatus's experience at work(Thoha, 2012).

With the mature abilities possessed by these officials, it can eliminate the negative image 


\section{International Journal of Business Management and Economic Review}

Vol. 4, No. 04; 2021

ISSN: 2581-4664

from society. Based on the results of respondents' perceptions of the ability of the apparatus, there are a number of things that must be of concern to the leadership and management of the SetdakabPijay, namely the ability to prepare work plans and the level of participation in training related to their respective areas of duty. These two things must receive the full attention of the SekdakabPijay leadership so that with the handling of these two things it is hoped that it will further improve the ability of the state civil apparatus and work motivation will also increase as well.

Testing the Effect of Apparatus Ability on Public Service Performance at the SetdakabPijay (Hypothesis 3)

The results of hypothesis testing directly influence the ability of the apparatus on the performance of public services at the SetdakabPijay, the Critical ratio (C.R) value of 6.312 is obtained, where this value is greater than the cut-off value of 1.96. The significance or probability value is 0.001 where this value is also less than 0.05 . These results indicate the ability of the apparatus has a positive and significant effect on the performance of public services at the SetdakabPijay or it can be called direct hypothesis testing (H3) is accepted which results in Ha3 accepted and $\mathrm{H} 03$ rejected. The magnitude of the influence of the ability of the apparatus on work motivation is 0.754 or $75.4 \%$. The results of this study are in line with the results of research conducted by(Rahma et al., 2017), (Ridwan \& Novigasa, 2016), (Sutaya, 2015), (Tian et al., 2016), (Rambi et al., 2015)and(Hasanah, 2019)who found that the ability of employees has a significant effect on performance.

These results prove that the better the abilities and expertise possessed by the apparatus, the better the performance of public services they produce. The ability of the apparatus greatly impacts the quality of public services. Professionalism is a reflection of the skills and expertise of the apparatus that can run effectively if it is supported by the suitability of the level of knowledge on the basis of educational background with the workload that is their responsibility and also as a reflection of the self-potential of the apparatus, both in terms of abilities and aspects of behavior which include loyalty. , innovation, productivity, and creativity(Mathis \& Jackson, 2006).

Based on the research results and the theoretical support, Pidie Jaya Regency Government must always strive to improve the performance of public services. The SetdakabPijay must be able to improve the performance of its public services again by improving the place and service facilities, cleanliness and comfort of service places, and the ease of obtaining services felt by the community because from the perceptions of respondents these three things get the lowest score even though they are included in the category good.

Other things that must get the attention of the SetdakabPijay leadership are efforts to increase the ability of the apparatus in compiling and implementing activity plans which are their main duties and functions, efforts to increase apparatus interest in participating in training related to their field of work, and providing opportunities for all employees to take part in selfdevelopment programs, opportunities to innovate and be creative in carrying out tasks and work procedures assigned to him. With the increase in the matters mentioned above, it is hoped that it will provide an increase in the ability of the apparatus and the performance of public services in the SetdakabPijay. 
International Journal of Business Management and Economic Review

Vol. 4, No. 04; 2021

ISSN: 2581-4664

Testing the Effect of Work Motivation on Public Service Performance at the SetdakabPijay (Hypothesis 4)

The results of testing the direct hypothesis of the effect of work motivation on the performance of public services at the SekdakabPijay obtained a Critical ratio (C.R) value of 2.549 where this value is greater than the cut-off value of 1.96 . The value of significance or probability is 0.000 where this value is also less than 0.05 . These results indicate that work motivation has a positive and significant effect on the performance of public services at the SetdakabPijay or it can be called direct hypothesis testing (H4) is accepted which results in $\mathrm{Ha} 4$ being accepted and $\mathrm{H} 04$ being rejected. The magnitude of the influence of the ability of the apparatus on work motivation is 0.268 or $26.8 \%$. The results of this study are in line with the results of studies that have been conducted by(Bawono, Setyadi, \& Hamid, 2020), (Rahma et al., 2017), (Tahir, 2016), (Sutaya, 2015)and(Idris, 2012)where the results of their research also proved that work motivation has a positive and significant effect on service performance.

The results of this study prove that in the SetdakabPijay environment if the work motivation of each apparatus is getting better, the better the performance of the resulting public services will be. Motivation is a positive effort in mobilizing, mobilizing, and directing the power and potential of the workforce in order to productively succeed in achieving and realizing the goals that have been previously set and as an incentive to be able to mobilize, mobilize and direct the potential and human work power in the desired direction. There are three key elements in motivation, namely effort, organizational goals, and needs. To be able to continue to increase the work motivation of their employees, the leadership of the SetdakabPijay must always maintain these efforts. Another thing that must be improved by the leadership of the Regional Secretariat in an effort to increase work motivation is to provide opportunities for all employees to improve their competence, giving confidence and responsibility for the job duties carried out by each employee.

\section{Indirect Effect Hypothesis Testing (Mediation Effect of Hypothesis 5)}

Testing TheEffect of Apparatus Ability on Public Service Performance through Work Motivation (Hypothesis 5)

To find out the mediating effect of work motivation on the relationship between the ability of the apparatus to the performance of public services, this study uses the help of a single test calculator using an unstandardized estimate value. The test results using the Sobel calculator are shown in Figure 3 below.

\begin{tabular}{|c|c|c|c|c|}
\hline Input: & & Test statistic: & Std. Error: & $p$-value: \\
\hline a 0.765 & Sobel test: & 5.88582897 & 0.09436054 & 0 \\
\hline$b 0.726$ & Aroian test: & 5.87619687 & 0.09451521 & 0 \\
\hline$s_{a} 0.047$ & Goodman test: & 5.8955086 & 0.09420561 & 0 \\
\hline$s_{\mathrm{b}} 0.115$ & Reset all & & Calculate & \\
\hline
\end{tabular}

Figure 3. Sobel Test for Mediation Effect 


\section{International Journal of Business Management and Economic Review}

Vol. 4, No. 04; 2021

ISSN: 2581-4664

From the results of hypothesis testing, the indirect effect of the ability of the apparatus on the performance of public services through work motivation shows a statistical test result of 5.885 where this value is greater than the cut-off value of 1.96 and the p-value is $0.000<0.05$. These results indicate that hypothesis 5 testing is accepted where Ha5 is accepted and H05 is rejected. So with this proves that work motivation mediates the effect of the ability of the apparatus on the performance of public services at the SetdakabPijay.

Based on the results of the significance calculation for line $\mathrm{C}$ 'using the Sobel test, it can be visualized a chart for all paths $\mathrm{A}, \mathrm{B}, \mathrm{C}$, and $\mathrm{C}^{\prime}$ to test the effect of the ability of the apparatus on the performance of public services at the SetdakabPijaythrough work innovation as shown in the following image.

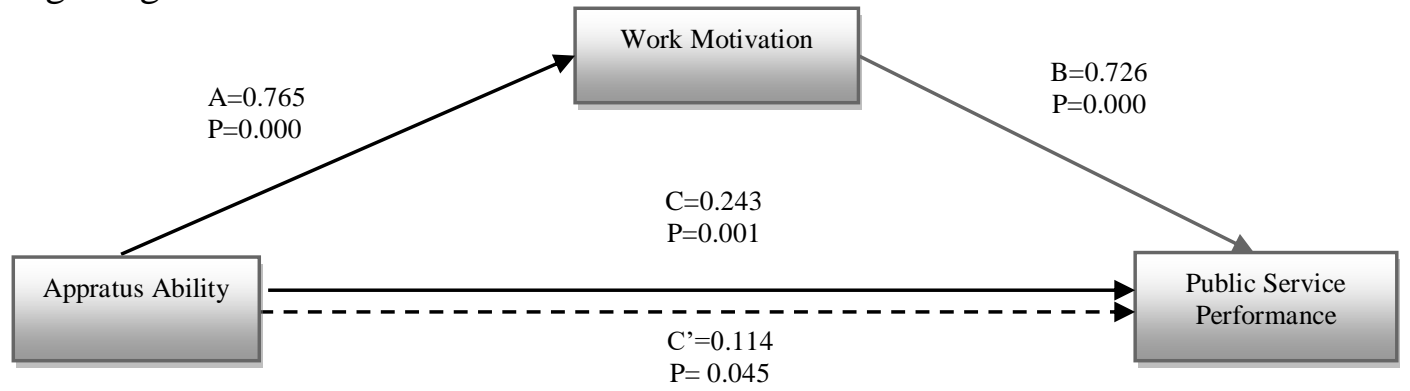

Figure 4. Mediation Effect Result

In Figure 4 above, it can be explained that the variable of the ability of the apparatus has an effect on work motivation by explaining that the coefficient of path $A$ has a value of $\beta=0.765$ and a value of $p=0.000<0.05$. Path $B$, namely work motivation affects the performance of public services which has a value of $\beta=0.726$ and a value of $p=0.000<0.05$. As well as path $C$, namely the ability of the apparatus to affect the performance of public services has a value of $\beta=$ 0.243 and $\mathrm{p}$-value $=0.001<0.05$. From the values of paths $\mathrm{A}, \mathrm{B}$, and $\mathrm{C}$, it can be concluded that they are significant. Line $C$ 'has a value of $\beta=0.555(0.765 \times 0.726=0.555)$ and a $\mathrm{p}$-value $=$ $0.000<0.05$. This value indicates that pathways $\mathrm{A}, \mathrm{B}, \mathrm{C}$, and $\mathrm{C}$ 'are significant or often referred to as partial mediation. The magnitude of the mediating role of work motivation on the effect of the ability of the apparatus on the performance of public services is 0.555 or $55.5 \%$.

\section{CONCLUSION}

The results of the research at the SetdakabPijay can be concluded as follows :

1) The results of the descriptive hypothesis testing (H1) show that the variables of the ability of the apparatus, work motivation, and performance of public services at the SetdakabPijay are already in good condition. This can be seen from the acquisition of the mean value of each variable above 3.41 and the probability value is less than 0.05 .

2) The results of direct hypothesis testing indicate that the ability of the apparatus has a positive and significant effect on work motivation (H2), the ability of the apparatus has a positive and significant effect on public service performance (H3), and work motivation has a positive and significant effect on public service performance $(\mathrm{H} 4)$. 


\section{International Journal of Business Management and Economic Review}

Vol. 4, No. 04; 2021

ISSN: 2581-4664

3) The results of the indirect hypothesis testing (H5) prove that work motivation partially mediates the effect of the ability of the apparatus on the performance of public services at the SetdakabPijay.

Thus, the results of the model test prove that the public service performance improvement model at the SekdakabPijay is acceptable, namely to improve public service performance the predictor that must be improved is the apparatus ability, so that it will have a direct impact on public service performance or will affect the increase in work motivation at the beginning and ends in improving public service performance. This can be a reference for further research, so that further researchers can develop this tested model by adding other variables such as workload, organizational citizenship behavior, and compensation.

Furthermore, based on the result analysis, several recommendations are provided for the SetdakabPijay leaders as practitioners as follows.

1. In order to improve the performance of public services, the SetdakabPijay must be able to improve the performance of its public services again by increasing the place and service facilities, cleanliness and comfort of service places, as well as the ease of obtaining services that are felt by the community because of the perceptions of respondents these three things are getting the lowest score even though it is in a good category.

2. In the work motivation variable, the SetdakabPijay leaders need to further increase work motivation for their employees, especially providing opportunities for employee selfimprovement, both further studies at higher levels, as well as other non-formal educations that are able to improve the abilities of their employees. This can be done by allocating a budget for employee development.

3. In the variable of the ability of the apparatus, the leadership of the SetdakabPijay needs more to improve the ability of their employees in preparing work plans and the level of participation in training related to their respective fields of work. These two things must receive the full attention of the Setdakab leadership, so that with the handling of these two things it is hoped that it will further improve the ability of the state civil apparatus.

\section{REFERENCES}

Anyim, C. F., Chidi, O. C., \& Badej, A. E. (2012). Motivation and Employee's Performance in Public and Private Sector in Nigeria. International Journal of Business Administration, 3(1), 31-40. https://doi.org/10.5430/ijba.v3n1p31

Bawono, I. R., Setyadi, E., \& Hamid, S. A. (2020). Work Motivation Effect on State Civil Apparatus Performance during WFH with Discipline Variable. Akrual Jurnal Akuntansi, 11(2), 110-121. https://doi.org/http://dx.doi.org/10.26740/jaj.v11n2.p110-121

Eko, W. S. (2015). Manajemen Pengembangan Sumber Daya Manusia. Yogyakarta: Pustaka Pelajar.

Elwan, L. O. M. (2019). Problem Birokrasi Dalam Meningkatan Pelayanan Publik Pada Sekretariat Daerah Kabupaten Muna. Jounal Publiuho, 2(2), 31-42. Retrieved from http://ojs.uho.ac.id/index.php/PUBLICUHO

Gibson, C. H. (1991). A Concept Analysis of Empowerment. Journal of Advanced Nursing, 16, 


\section{International Journal of Business Management and Economic Review}

Vol. 4, No. 04; 2021

ISSN: 2581-4664

354-361. https://doi.org/http://dx.doi.org/10.1111/j.1365-2648.1991.tb01660.x

Halik, A. (2016). Pengaruh Bauran Pemasaran Jasa, Kualitas Layanan Dan Nilai Religiusitas Terhadap Kepercayaan Nasabah Dan Imlikasinya Pada Komitmen Nasabah Bank Umum Syariah Di Wilayah Gerbang Kertasusila Jawa Timur. Jurnal Hasil Penelitian LPPM Untag Surabaya, 1(1), 123-148.

Handayaningrat, S. (1986). Landasan dan pedoman kerja administrasi pemerintah daerah, kota dan desa. Jakarta: Gunung Agung.

Hasanah, N. U. (2019). Analisis Pengaruh Kinerja Keuangan Terhadap Zakat Perusahaan (Studi Kasus Pada Bmt Di Sleman). UIN Sunan Kalijaga.

Hasibuan. (2014). Manajemen Sumber Daya Manusia. In Manajemen Sumber Daya Manusia (Revisi). Jakarta: Bumi Aksara.

Humas-Pijay. (2015). Rencana Kerja Pemerintah Kabupaten (RKPK) Pidie Jaya. Pidie Jaya.

Idris, A. (2012). Pengaruh Motivasi Kerja Dan Jiwa Kewirausahaan Terhadap Kinerja Pelayanan Aparatur SKPD Dan Implikasinya Pada Kualitas Pelayanan Publik Di Provinsi Aceh. Jurnal Ekonomika, III(5), 9-23.

Kasmi. (2017). Pengaruh Kemampuan Dan Motivasi Kerja Pegawai Terhadap Kualitas Pelayanan Masyarakat Di Kantor Kependudukan Dan Catatan Sipil Kabupaten Pringsewu. Jurnal Aktual STIE Trisna Negara, 15(1), 53-60.

Kian, T. S., \& Yusoff, W. F. W. (2015). Motivation and Promotion Opportunity of Academic Citizens towards Open Innovation: Proposed Model. Procedia - Social and Behavioral Sciences, 204, 29-35. https://doi.org/https://doi.org/10.1016/j.sbspro.2015.08.106

Maduka, C. E., \& Okafor, O. (2014). Effect of Motivation on Employee Productivity: A Study of Manufacturing Companies in Nnewi. International Journal of Managerial Studies and Research (IJMSR), 2(7), 137-147.

Mathis, R. L., \& Jackson, J. H. (2006). Human resource management: Manajemen sumber daya manusia. In Terjemahan Dian Angelia. Jakarta: Salemba Empat. Jakarta: Salemba Empat.

Muttaqin, N. I., Djumadi, \& Noor, M. (2013). Pengaruh Motivasi Kerja Terhadap Pelayanan Publik Di Kantor Camat Tenggarong Kabupaten Kutai Kartanegara. EJournal Administrative Reform, 1(1), 246-256.

Nirwandar, S., Tadju, I., \& Moerdiono. (1992). Birokrasi dan administrasi pembangunan: beberapa pemikiran pemecahan. Jakarta: Pustaka Sinar Harapan.

Omolo, P. A. (2015). Effect of motivation on employee performance of commercial banks in Kenya: A case study of Kenya Commercial Bank in Migori County. International Journal of Human Resource Studies, 57-103. https://doi.org/https://doi.org/10.5296/ijhrs.v5i2.7504

Rahma, I. wulan, Mattalatta, \& Abdullah, R. (2017). Pengaruh Kemampuan Kerja Dan Motivasi Kerja Terhadap Kualitas Pelayanan Pajak Bumi Dan Bangunan Kabupaten Soppeng. Jurnal Mirai Management, 2(2), 283-294. 


\section{International Journal of Business Management and Economic Review}

Vol. 4, No. 04; 2021

ISSN: 2581-4664

Rahmad. (2014). Pengaruh Perilaku Aparatur Terhadap Kualitas Pelayanan Publik Di Kantor Camat Bunta Kabupaten Banggai. E-Jurnal Katalogis, 2(1), 53-61.

Rambi, R., Lengkong, V. P. K., \& Jorie, R. J. (2015). Pengaruh Praktek-Praktek Manajemen Sumber Daya Manusia Terhadap Kinerja Pegawai Pada PT. PLN (Persero)Wilayah Sulutenggo. Jurnal Berkala Ilmiah Efisiensi, 15(5), 622-634.

Ratminto, \& Winarsih, A. S. (2008). Manajemen Pelayanan: Pengembangan Model Konseptual, Penerapan Citizen's Charter dan Standar Pelayanan Minimal. Yogyakarta: Pustaka Pelajar.

Ridwan, M., \& Novigasa, A. (2016). Pengaruh Kemampuan Kerja Aparatur Pemerintah Daerah terhadap Kualitas Pelayanan Publik (Studi Kasus di Dinas Kependudukan dan Pencatatan Sipil Kota Pekanbaru Tahun 2014). JOM FISIP, 3(1), 1-14.

Robbins, S. P., \& Judge, T. A. (2012). Organizational Behavior (15th ed.; S. Yagan, Ed.). San Diego: Pearson.

Salijana, R., Toha, A., \& Helpiastuti, S. B. (2019). The Performance of Government Official at The Demography and Civil Department in Situbondo Observed by Competence, Motivation and Commitment Aspect. ISSRD Journal, 2(1), 45-60. https://doi.org/10.19184/issrd.v2i2.17471

Soetopo. (1999). Pelayanan Prima. Jakarta: LAN RI.

Sutaya, I. M. (2015). Pengaruh Motivasi Dan Kemampuan Aparat Terhadap Kualitas Pelayanan Pajak Bumi Dan Bangunan Di Dinas Pendapatan Dan Pesedahan Agung Di Kabupaten Tabanan, Propinsi Bali. Jurnal Penelitian Administrasi Publik, 1(2), 314-330.

Tahir, N. (2016). Motivasi Kerja Pegawai Dalam Pelayanan Publik Di Sekretariat Pemerintah Daerah Kabupaten Takalar. Jurnal Ad'ministrare, 3(2), 1-10. https://doi.org/https://doi.org/10.26858/ja.v3i2.2423

Tayibnapis, F. Y. (1989). Evaluasi program. Jakarta: P2LPTK.

Thoha, M. (2012). Perilaku Organisasi : Konsep Dasar dan Aplikasinya. Jakarta: Rajawali Pers.

Tian, A. W., Cordery, J., \& Gamble, J. (2016). Returning the Favor: Positive Employee Responses to Supervisor and Peer Support for Training Transfer. International Journal of Training and Development, 20(1), 1-16.

Tjiptono, F. (1996). Manajemen Jasa. Yogyakarta: Andi.

Wright, B. E., \& Pandey, S. K. (2008). Public Service Motivation and the Assumption of Person-Organization Fit: Testing the Mediating Effect of Value Congruence. Administration \& Society, 40(5), 502-521. https://doi.org/0.1177/0095399708320187 